\title{
PRAKTIK KEAMANAN MANUSIA SOKA GAKKAI INTERNATIONAL DI INDONESIA, FILIPINA, DAN SINGAPURA KETIKA PANDEMI COVID-19
}

\author{
Muhammad Fikry Anshori ${ }^{1}$ dan Susy Ong² \\ ${ }^{1}$ Kajian Wilayah Jepang, Universitas Indonesia; muhammad.fikry01@ui.ac.id \\ ${ }^{2}$ Kajian Wilayah Jepang, Universitas Indonesia; susy.ong66@gmail.com
}

\begin{abstract}
This research aims to identify and describe the practices carried out by Soka Gakkai International (SGI) that are concerned with global issues such as human rights and sustainable development, to support human security in Indonesia, the Philippines and Singapore during the Covid-19 pandemic? Using a qualitative approach, case study methods and literature studies as well as a human security conceptual framework, this research was conducted. The results showed various practices of Soka Gakkai International that supported efforts to protect humans from the threat of Covid-19 in Indonesia, the Philippines and Singapore from March to July 2020. However, there are pros and cons among experts regarding SGI's human security practices during the pandemic. This can be a lesson about human safety practices during a pandemic.
\end{abstract}

Keywords: Covid-19, human security, Soka Gakkai International

\begin{abstract}
Abstrak
Penelitian ini bertujuan untuk mengidentifikasi dan mendeskripsikan praktik-praktik yang dilakukan oleh Soka Gakkai International (SGI) yang hirau dengan isu-isu global seperti hak asasi manusia dan pembangunan berkelanjutan, untuk mendukung keamanan manusia di Indonesia, Filipina, dan Singapura ketika terjadi pandemi Covid-19? dengan menggunakan pendekatan kualitatif, metode studi kasus dan studi literatur serta kerangka konsep keamanan manusia penelitian ini dilakukan. Hasil penelitian menunjukkan berbagai praktik Soka Gakkai International yang mendukung upaya perlindungan manusia dari ancaman Covid-19 di Indonesia, Filipina, dan Singapura dari bulan Maret hingga Juli 2020. Namun, terdapat pro dan kontra di antara pakar mengenai praktik keamanan manusia dari SGI ketika pandemi. Hal ini dapat menjadi pembelajaran mengenai praktik keamanan manusia pada saat pandemi berlangsung.
\end{abstract}

Kata Kunci: Covid-19, keamanan manusia, Soka Gakkai International 


\section{Pendahuluan}

Sistem global saat ini sudah tidak lagi menjadikan negara sebagai aktor utama. Keberadaan aktor non-negara, baik berorientasi laba maupun nirlaba, membentuk jaringan yang memberikan konsekuensi penting dalam politik global. Tindakan aktor non-negara di suatu kawasan dapat berdampak bagi belahan dunia lain. Dengan kata lain, berbagai upaya untuk membentuk tatanan berlangsung dalam konteks global (McGrew, 2014: 29). Pergeseran juga berlangsung di bidang keamanan dengan perluasan pemahaman mengenai ancaman. Militer negara lain tidak lagi dianggap sebagai ancaman utama yang membahayakan. Penyakit, kemiskinan, kelaparan, kejahatan, dan bencana termasuk dalam ancaman yang mendesak. Berbagai hal ini dapat menghancurkan keberlangsungan hidup individu, masyarakat, maupun pemerintah (Hough, 2013: 16-19).

Soka Gakkai International (SGI) adalah Non-Governmental Organization umat Budha ajaran Nichiren, seorang biksu Jepang di abad ke-13, yang memiliki praktik sehari-hari berupa pelantunan "Nam-Myoho-Renge-Kyo" (Daimoku) dan pembacaan kitab Lotus Sutra (Soka Gakkai International, 2015a: 4-7). SGI dimulai dengan pembentukan Soka Gakkai (Masyarakat Penciptaan Nilai) oleh Makiguchi Tsunesaburo dan Toda Josei pada tahun 1930 di Jepang. Ikeda Daisaku, murid Toda Josei, secara resmi mentransformasi Soka Gakkai menjadi SGI pada tahun 1975 dengan pertumbuhan keanggotaan dari berbagai negara (Soka Gakkai International, 2015a: 11-15). Anggota SGI berjumlah 2 juta orang dan tersebar di 192 negara pada tahun 2015. SGI memiliki ikatan resmi dengan United Nations (UN) untuk berkolaborasi dalam pelucutan senjata nuklir, hak asasi manusia, pembangunan berkelanjutan, serta bantuan kemanusiaan (Soka Gakkai International, 2015a: 1-3). ${ }^{1}$

Terdapat beberapa kajian yang mendiskusikan praktik SGI di berbagai isu dalam lima tahun terakhir. McLaughlin (2016) membahas tentang pembelajaran yang dapat diperoleh dari SGI dalam hal penyaluran bantuan kemanusiaan kepada korban gempa. Gagné (2017) menelaah

\footnotetext{
1 Ajaran Nichiren menitikberatkan pada mewujudkan potensi bawaan seseorang untuk bertanggung jawab dan berkontribusi secara proaktif dalam menemukan solusi bagi berbagai permasalahan di dunia. SGI adalah organisasi yang didedikasikan untuk menghidupkan dan menyiarkan humanisme sebagai inti dari ajaran Budha. Humanisme yang dimaksud adalah kebahagiaan diri sendiri dan orang lain dengan dasar rasa percaya, penciptaan nilai, dan harmoni. SGI berkomitmen untuk mempromosikan perdamaian dunia dan penghormatan martabat manusia (Soka Gakkai International, 2015b: 19-21). Referensi lebih lanjut mengenai sejarah perkembangan SGI, penyebarluasan ajaran Buddha Nichiren, serta pergerakan SGI dalam berbagai isu dapat merujuk ke Machacek \& Wilson (2000), Seager (2006), Fisker-Nielsen (2012), Cherry \& Ebaugh (2016), dan Goulah (2020).
} 
globalisasi ajaran Budhisme Nichiren dengan pembentukan organisasi perwakilan SGI serta perekrutan anggota baru di berbagai negara. Yuri (2017) mendeskripsikan karakteristik dari kampanye SGI dalam isu gender yang memperjuangkan hubungan konsensual antara laki dan perempuan. Panno dkk (2018) membahas tentang dukungan SGI terhadap upaya perlindungan lingkungan hidup dengan mengampanyekan realita perubahan iklim. Šorytė (2019) menelusuri perkembangan kampanye SGI dalam isu pelucutan nuklir sejak tahun 1957 yang memiliki jargon "nuklir adalah setan sejati".

Pada tanggal 11 Maret 2020, Tedros Adhanom selaku Direktur Jenderal World Health Organization (WHO) mengumumkan Covid-19 sudah menjadi pandemi global (World Health Organization, 2020a: 7). Covid-19 adalah penyakit menular yang disebabkan oleh virus korona jenis baru. Virus dan penyakit tersebut belum pernah diketahui sebelumnya dan baru terdeteksi di Wuhan, China pada bulan Desember 2019. Virus korona jenis baru ini menyerang sistem pernafasan manusia dan hewan dengan gejala umum berupa demam, rasa lelah, dan batuk kering. Secara bertahap, penderita Covid-19 mengalami nyeri badan, hidung tersumbat, sakit kepala, sakit tenggorokan, diare, kehilangan kemampuan membau dan mengecap, ruam di kulit, atau perubahan warna jari (World Health Organization, 2020b: 1-3).

Tabel 1 - Penyebaran COVID-19 di Kawasan Asia Tenggara terhitung 31 Juli 2020

\begin{tabular}{ll}
\hline Negara & Jumlah Kasus Terkonfirmasi \\
\hline Brunei Darussalam & 141 \\
\hline Filipina & 89.374 \\
\hline Indonesia & 106.336 \\
\hline Kamboja & 234 \\
\hline Laos & 20 \\
\hline Malaysia & 8.964 \\
\hline Myanmar & 353 \\
\hline Singapura & 51.809 \\
\hline Thailand & 3.310 \\
\hline Vietnam & 509 \\
\hline
\end{tabular}

Sumber: (World Health Organization, 2020c)

Terdapat 17 juta kasus Covid-19 yang sudah terkonfirmasi secara global terhitung 31 Juli 2020. Peningkatan kasus terkonfirmasi secara global berkisar 200 ribu per hari. Kawasan Asia Tenggara menempati peringkat keempat dalam penyebaran Covid-19 setelah Amerika, Eropa, dan 
Mediterania Timur dengan total 2 juta kasus terkonfirmasi terhitung 31 Juli 2020. Jumlah tersebut setara dengan 993 kasus terkonfirmasi per satu juta orang (World Health Organization, 2020c). Tabel 1 memperlihatkan distribusi jumlah kasus Covid-19 negara-negara di Asia Tenggara terhitung hingga 31 Juli 2020. Jumlah kasus Covid-19 terkonfirmasi dari negara-negara di Asia Tenggara beragam. Dari belasan hingga ratusan ribu. Tiga negara di Asia Tenggara dengan jumlah kasus Covid-19 terkonfirmasi terbesar adalah Indonesia, Filipina, dan Singapura.

Pandemi Covid-19 menjadi tantangan keamanan manusia di berbagai belahan dunia. Terlebih bagi masyarakat di negara dengan kasus Covid-19 terkonfirmasi sangat tinggi seperti Indonesia, Filipina, dan Singapura. Kontribusi setiap aktor sangat diperlukan untuk menanggulangi dampak yang diakibatkan oleh Covid-19. Terkait kontribusi SGI sebagai NonGovernmental Organization (NGO) yang dapat dikatakan aktif dalam beberapa isu internasional, pertanyaannya adalah bagaimana praktik-ptaktik yang dilakukan SGI untuk mendukung upaya keamanan manusia di Indonesia, Filipina, dan Singapura ketika pandemi Covid-19? Untuk menjawab pertanyaan tersebut, artikel ini mengenalkan terlebih dahulu konsep keamanan manusia. Setelah itu, akan dipaparkan metode yang digunakan dalam artikel ini. Selanjutnya, pembahasan mengenai praktik SGI di tiga negara tersebut yang mencirikan praktik keamanan manusia. Terakhir, artikel ini ditutup dengan simpulan dan saran.

\section{Konsep Non-Governmental Organization (NGO) dan Konsep Keamanan Manusia}

\section{Konsep NGO}

Non-Governmental Organization (NGO) adalah salah satu jenis organisasi internasional beranggotakan kelompok masyarakat yang didirikan di berbagai negara dengan tujuan merancang dan menjalankan projek terkait pembangunan atau bantuan. Bidang yang dijalani oleh NGO antara lain mitigasi bencana, pengentasan kemiskinan, pemberdayaan perempuan, dan perlindungan lingkungan. NGO juga hadir untuk mempromosikan atau memperjuangkan isu tertentu (Heywood, 2011: 6). NGO berbeda dengan jenis organisasi internasional lainnya yaitu International Governmental Organization (IGO) yang beranggotakan minimal tiga negara dengan prosedur 
formal, aturan, atau kesepakatan untuk memfasilitasi pencapaian kepentingan nasional dan diplomasi antarnegara (Heywood, 2011: 433). ${ }^{2}$

Ada tiga dampak dari keberadaan NGO menurut Griffiths dkk (2008: 225) yaitu: 1) aktivitas NGO serupa atau bahkan dapat melampaui IGO yang dibentuk oleh negara; 2) NGO menandai kemunculan masyarakat sipil global; dan 3) NGO menegaskan signifikansi kapabilitas aktor nonnegara dalam hubungan internasional. Griffiths dkk (2008: 225) memberikan contoh bahwa sudah banyak NGO yang menjadi ahli dalam penyediaan dan penyaluran bantuan kemanusiaan. Bidang ini adalah salah satu yang tidak dapat mudah dilakukan oleh negara maupun IGO. NGO juga aktor yang tidak terikat dengan kedaulatan negara, sehingga dapat berinteraksi lebih leluasa di tingkat global. Oleh karena itu, NGO dapat menanggapi berbagai kebutuhan sosial, lingkungan, dan kesehatan masyarakat ketika pemerintah tidak sanggup karena alasan tertentu.

NGO sering diasosiasikan sebagai aktor yang mampu untuk memenuhi berbagai macam kebutuhan sosial ketika aktor seperti pemerintah tidak mampu melakukannya (Maya-Jariego dkk., 2020: 1212). Walaupun begitu, NGO memiliki keterbatasan berupa pendanaan dalam menjalankan program yang sudah mereka rencanakan. Durasi dan keberlanjutan aktivitas suatu NGO secara spesifik ditentukan sekali oleh dana yang tersedia. Dengan kata lain, NGO sebenarnya adalah aktor yang sangat bergantung dan berorientasi juga pada ketersediaan dana. Kondisi seperti ini menurut Maya-Jariego dkk (2020: 1213) memunculkan paradoks dalam aktivitas yang dilakukan oleh NGO karena tujuan mereka menjalankan program berada di antara profesionalitas secara sukarela atau pencarian sumber aliran pendanaan. Saat ini, paradoks tersebut masih menjadi perdebatan dalam kajian mengenai NGO. Oleh karena itu, hal ini membuat pentingnya perhatian lebih lanjut dengan cara mengangkat berbagai macam contoh kasus yang relevan (Maya-Jariego dkk., 2020: 1223).

\section{Konsep Keamanan Manusia}

Keamanan dapat dikatakan sebagai konsep yang dipertentangkan karena tidak ada kesepakatan tunggal untuk menjawab empat pertanyaan ini: 1) apa itu keamanan?; 2) keamanan siapa yang dibahas?; 3) apa yang dianggap sebagai isu keamanan?; serta 4) bagaimana keamanan dapat dicapai? (Williams, 2013: 5). Secara umum, keamanan sering diasosiasikan dengan pengurangan (alleviation) ancaman terhadap nilai yang berharga. Ancaman tersebut terutama yang bersifat

\footnotetext{
${ }^{2}$ Refrensi lebih lanjut mengenai Non-Governmental Organization yang direkomendasikan oleh Willets (2014) antara lain Weiss \& Gordenker (1996), Willets (1996), Heins (2008), Willets (2010), dan Davies (2019). 
mengganggu keberlangsungan hidup (survival) dari objek rujukan (referent object) tertentu di waktu dekat. Keamanan sering dianggap berkaitan dengan keberlangsungan hidup tetapi keduanya berbeda. Jika keberlangsungan hidup adalah kondisi yang menggambarkan keberadaan, keamanan melibatkan kemampuan untuk mencapai ambisi sosial dan politik (Williams, 2013: 6).

Ada dua pendekatan dalam keamanan yaitu tradisional dan non-tradisional. Pendekatan tradisional seperti realisme dan liberalisme menganggap objek rujukan utama dalam keamanan adalah negara dan ancaman utama dalam keamanan adalah serangan militer. Realisme dan liberalisme itu sendiri tidak memiliki kesepakatan dalam cara untuk mencapai keamanan. Realisme berorientasi pada perimbangan kekuatan militer, sedangkan liberalisme berorientasi pada institusi internasional (Carr \& Wallis, 2016: 7-12). Pendekatan non-tradisional seperti Konstruktivisme, Mazhab Kopenhagen, Keamanan Kritis, dan Keamanan Manusia secara sederhana berlawanan dengan tradisional. Pendekatan non-tradisional memberikan perhatian pada ancaman non-militer dan transnasional terhadap masyarakat dan negara yang membutuhkan penanganan komprehensif dan multilateral. Contohnya kerusakan lingkungan, bencana alam, dan penyakit menular (Carr \& Wallis, 2016: 12-16). ${ }^{3}$

Keamanan manusia memiliki konsepsi yang beragam. Ada yang menganggap keamanan manusia dilandasi oleh asumsi hak dasar setiap manusia untuk hidup, bebas, dan mengejar kebahagiaan serta kewajiban untuk melindungi dan mempromosikan hak tersebut. Pandangan lain menganggap keamanan manusia berkaitan dengan intervensi kemanusiaan (humanitarian intervention) untuk memperbaiki kondisi kehidupan dasar dari pengungsi atau berbagai pihak yang terdampak konflik bersenjata. Anggapan lain terhadap keamanan manusia adalah memberikan perhatian pada berbagai aspek seperti ekonomi, lingkungan, kesehatan, dan sosial yang dapat merusak penghidupan dan kesejahteraan setiap manusia (Hampson, 2013: 281). Konsep tersebut mengindikasikan banyak cara untuk mendefinisikan keamanan manusia. Salah satunya adalah ketiadaan ancaman terhadap berbagai nilai inti bagi keselamatan setiap manusia (Hampson, 2013: 282).

Malik (2015: 64-65) menyatakan pakar maupun praktisi menyepakati objek rujukan dalam keamanan manusia adalah individu atau kelompok masyarakat. Walaupun begitu, pertentangan muncul dalam nilai yang perlu ditegaskan. Nilai dari keamanan manusia bisa berupa

\footnotetext{
${ }^{3}$ Referensi lebih lanjut mengenai pendekatan tradisional dan non-tradisional yang sudah disebutkan di atas dapat merujuk ke Walt (1998), Snyder (2009), Dunne dkk (2013), Steans dkk (2013), dan McGlinchey dkk (2017).
} 
keberlangsungan hidup, pembangunan, keselamatan fisik, martabat, atau kebebasan personal. Pertentangan tersebut akibat dari ancaman yang dihadapi oleh manusia sangat beragam dan kompleks. Prezelj berupaya menyusun spektrum ancaman dalam keamanan manusia dan hasilnya adalah tiga belas kategori: 1) ekonomi; 2) pangan; 3) kesehatan; 4) lingkungan; 5) personal; 6) komunitas; 7) politik; 8) demografi; 9) kejahatan; 10) bencana alam; 11) konflik dan perang; 12) genosida; serta 13) ranjau darat dan senjata api (Malik, 2015: 65).

Ada lima aspek yang membedakan keamanan manusia dengan pendekatan keamanan tradisional: 1) berpusat pada orang: keamanan manusia diaplikasikan pada individu dan komunitas serta diarahkan pada perlindungan dan pemberdayaan populasi; 2) universal: keamanan manusia berlandaskan klaim semua manusia memiliki hak dasar untuk hidup dalam martabat; 3) banyak aktor: aktor keamanan manusia terdiri dari negara maupun non-negara; 4) multidimensional: keamanan manusia berimplikasi pada banyak bidang kebijakan seperti ekonomi, politik, dan sosial; serta 5) interdependen: tanggung jawab kolektif dengan dilandasi solidaritas dan kerja sama transnasional diperlukan untuk menangani ancaman keamanan manusia yang melintasi batas-batas negara. Lima aspek ini mengarah pada objektif dari keamanan manusia, yaitu menjamin keberlangsungan hidup dan martabat setiap manusia (Teitt, 2016: 244).

Jepang dan Kanada adalah negara terdepan dalam advokasi agenda keamanan manusia. Dua negara ini memiliki pertentangan dalam fokus keamanan manusia. Jepang fokus pada "kebebasan dari kekurangan" ("freedom from want") yang bersifat luas dan dalam, sedangkan Kanada berfokus pada "kebebasan dari ketakutan" ("freedom from fear") yang bersifat lebih sempit. Keamanan manusia versi Jepang didasarkan pada fakta kematian orang sehari-hari adalah hasil dari kemiskinan ekstrim dan pembangunan yang minim. Sementara itu, keamanan manusia versi Kanada didasarkan pada kehancuran sistemik yang disebabkan oleh perang sipil, genosida, konflik etnis, serta kejahatan kemanusiaan (Teitt, 2016: 245). Acharya (2001: 446-448) berpendapat bahwa keamanan manusia versi Jepang memprioritaskan promosi hak sosial dan ekonomi demi pembangunan, sedangkan keamanan manusia versi Kanada mengutamakan perlindungan keselamatan individual.

Di tengah perbedaan tersebut, hal yang sama-sama disepakati oleh Jepang maupun Kanada terkait praktik keamanan manusia adalah keterbukaan akan keterlibatan berbagai macam aktor dalam satu tindakan bersama. Setiap aktor dapat secara aktif mempromosikan dan menjalankan program maupun institusi untuk mendukung berbagai inisiatif keamanan manusia. Organisasi 
Non-Pemerintah (Non-Governmental Organization) sebagai salah satu dari aktor dalam hubungan internasional memiliki kontribusi bagi keamanan manusia dalam beberapa bentuk: 1) sebagai sumber informasi dan peringatan dini terkait ancaman keamanan manusia; 2) menyediakan saluran bantuan bagi orang yang rentan atau terdampak oleh ancaman;3) mendukung program pemerintah atau Organisasi Antar-Pemerintah (Intergovernmental Organization) dalam misi kemanusiaan; serta 4) menyebarluaskan pembangunan berkelanjutan ke masyarakat (Acharya, 2001: 456-461). ${ }^{4}$

Ruang lingkup yang luas dan masih diperdebatkan juga membuat berbagai tindakan dari suatu aktor tidak dapat dengan mudah dikatakan sebagai praktik keamanan manusia. Praktik keamanan manusia memfasilitasi berbagai intervensi yang tujuan utamanya belum tentu untuk memberikan perlindungan dan menyediakan sarana dalam menanggulangi suatu ancaman bagi masyarakat rentan di suatu wilayah geografis tertentu (Holliday \& Howe, 2011). Kondisi berbahaya memberikan dorongan dalam menjalankan tindakan yang cepat dan tanggap demi memecahkan permasalahan. Namun, kondisi tersebut juga dapat digunakan sebagai justifikasi yang mudah diterima oleh kalangan orang banyak untuk menutupi maksud-maksud tertentu. Holliday dan Howe (2011) menyebutkan ada kontradiksi dari keamanan manusia itu sendiri berupa tidak ada jaminan upaya perlindungan dapat dijalankan secara bertanggung jawab karena mengutamakan keterlibatan banyak aktor saja.

\section{Metodologi}

Artikel ini menggunakan metode studi kasus. Moses dan Knutsen (dalam Lamont, 2015: 127-128) menyatakan kasus adalah kejadian spesifik, lampau maupun terkini, dengan titik awal dan akhir yang jelas. Artikel ini mengangkat praktik-praktik SGI di Indonesia, Filipina, dan Singapura dari tanggal 11 Maret 2020 hingga 31 Juli 2020. Periode tersebut mengacu pada pengumuman oleh WHO bahwa Covid-19 telah menjadi pandemi global pada waktu penulisan artikel ini. Teknik pengumpulan data yang digunakan adalah studi berbasis internet serta studi berbasis literatur. Studi berbasis internet dilakukan terhadap publikasi daring dari SGI seperti berita, laporan kegiatan, atau siaran pers. Sementara itu, studi berbasis literatur dilakukan terhadap kajian terkini dengan fenomena yang sama yaitu praktik SGI ketika Covid-19. Sumber data dari artikel ini merujuk pada

\footnotetext{
${ }^{4}$ Acharya (2014) juga merekomendasikan bacaan lebih lanjut mengenai keamanan manusia antara lain United Nations Development Programme (1995), Haq (1995), Commision of Human Security (2003), Tajbakhsh \& Chenoy (2006), dan Duffiled (2007).
} 
situs dan media sosial resmi milik SGI, Google Scholar, JSTOR, SAGE Journals, serta ScienceDirect.

Teknik analisis data yang digunakan dalam artikel ini adalah analisis runtun waktu (timeseries analysis). Teknik ini dijalankan dengan cara menggambarkan keterhubungan kejadian dalam jangka waktu tertentu yang dapat berupa: 1) suatu kejadian terjadi sebelum atau sesudah kejadian lain; 2) suatu kejadian berlangsung bersamaan dengan kejadian lain; 3) suatu kejadian mengikuti kejadian lain setelah jangka waktu tertentu; atau 4) suatu kejadian berlangsung secara berbeda di waktu lain. Urutan kronologis seperti ini andal untuk mengusut suatu kejadian, sehingga dapat memperoleh temuan yang berarti (Yin, 2018: 150-155). Dengan analisis runtun waktu, aktivitas SGI di Indonesia, Filipina, dan Singapura yang mencirikan praktik keamanan manusia serta pendapat berbagai pakar mengenai hal tersebut dapat teridentifikasi.

\section{Aspek Keamanan Manusia dari Praktik SGI di Indonesia, Filipina, dan Singapura ketika}

\section{Covid-19}

\section{Praktik-praktik SGI di Indonesia, Filipina, dan Singapura ketika Covid-19}

Pada periode awal pandemi, SGI menanggapi Covid-19 di Indonesia dengan seruan melalui media sosial untuk tetap waspada dan tidak perlu panik. SGI mengajak penduduk Indonesia untuk menjaga kebersihan dan daya tahan tubuh, mengikuti panduan yang diberikan oleh Kementerian Kesehatan Republik Indonesia (Kemenkes RI), serta menghubungi dan menyemangati orangorang sekitar sebagai wujud perhatian (SokaGakkaiIndonesiainfo, 2020a; SokaGakkaiIndonesiainfo, 2020b). Selain itu, SGI juga menyebarluaskan informasi bagi penduduk Indonesia tentang cara yang dapat dilakukan setiap orang untuk menghentikan penyebaran Covid-19: 1) beraktivitas di rumah saja; 2) rajin cuci tangan; 3) jaga jarak; 4) hindari menyentuh mata, mulut, dan hidung; serta 5) segera hubungi perawatan medis ketika terserang demam, batuk, dan sulit bernapas (SokaGakkaiIndonesiainfo, 2020c).

Pada tanggal 27 Maret 2020, SGI menyalurkan bantuan bagi penduduk lansia di Singapura yang tinggal seorang diri tanpa keluarga. Paket bantuan bernama "Care Pack" ini terdiri dari barang-barang penting untuk menghadapi pandemi Covid-19 yaitu masker, cairan pembersih tangan, serta bahan makanan pokok seperti beras (Soka.Singapore, 2020a). Penyaluran bantuan dilakukan oleh perwakilan anggota SGI di Singapura dengan cara mengunjungi langsung ke 
tempat tinggal. Selain itu, penduduk lansia juga diberikan informasi terkait perkembangan Covid19 di Singapura agar tetap mengetahui kondisi terkini. Mereka mengatakan penyaluran bantuan ini merupakan sikap perhatian di tengah periode yang penuh tantangan terutama bagi kalangan lansia di Singapura (Singapore Soka Association, 2020a).

Praktik selanjutnya dari SGI di Singapura ketika pandemi Covid-19 adalah distribusi cairan pembersih tangan secara cuma-cuma ke masyarakat pada tanggal 30 Maret 2020. Praktik ini sebenarnya termasuk dalam bagian gerakan nasional oleh seluruh NGO yang ada di Singapura (Soka.Singapore, 2020b). Anggota SGI di Singapura menjadi sukarelawan dalam distribusi massal dengan membuka pos penyaluran di beberapa pusat komunitas masyarakat (gedung serbaguna, gedung olahraga, dll). Penduduk Singapura cukup diminta untuk datang ke tempat dengan membawa botol air kosong yang nanti akan diisi $500 \mathrm{ml}$ cairan pembersih tangan oleh anggota SGI. Pelaksanaan kegiatan memperhatikan protokol kesehatan untuk mencegah penyebaran Covid-19 seperti pengukuran suhu tubuh sebelum masuk gedung dan jaga jarak (Singapore Soka Association, 2020b).

Pada tanggal 15 April 2020, anggota SGI di Indonesia menyalurkan bantuan seribu Alat Pelindung Diri (APD) ke Pusat Krisis Kesehatan Kemenkes RI. APD ini ditujukan bagi tenaga medis yang berjuang dalam penanganan pandemi Covid-19. Bantuan diserahkan langsung oleh anggota perwakilan SGI di Indonesia (SokaGakkaiIndonesiainfo, 2020d; SGI Indonesia, 2020). Selain itu, anggota SGI di Indonesia juga mulai berinisiatif untuk membuka produksi masker kain pada bulan April ini. Masker kain tersebut diproduksi secara massal oleh anggota SGI di Indonesia itu sendiri. Masker kain dirancang dengan mengikuti standar dari WHO yaitu setidaknya memiliki dua lapis kain. Hasil produksi lalu dibagikan gratis ke masyarakat (SokaGakkaiIndonesiainfo, 2020e).

Produksi dan distribusi masker kain juga dilakukan oleh SGI di Singapura pada bulan April. Anggota SGI di Singapura mengembangkan pembuatan masker kain sebagai langkah sederhana untuk membantu ketersediaan alat kesehatan. Masker kain dipilih mereka karena tidak mahal, dapat dipakai berulang kali, dan andal untuk menjaga diri selama pandemi Covid-19 berlangsung. Selain itu, anggota SGI di Singapura juga membuat masker kain yang cocok bagi anak-anak dengan motif kartun. Masker kain khusus anak menjadi permasalahan tersendiri di Singapura karena tidak banyak tersedia bagi masyarakat. Hasil pembuatan masker kain didistribusikan ke masyarakat secara cuma-cuma. Kemudian, SGI di Singapura mengembangkan juga tempat 
pelatihan pembuatan masker kain bagi penduduk Singapura agar lebih banyak orang yang dapat membuat sendiri (Singapore Soka Association, 2020c).

Pada tanggal 8 Mei 2020, SGI di Singapura mengumumkan akan berkolaborasi dengan Singapore Red Cross (SRC) untuk menggelar aksi donor darah. Aksi ini bertujuan untuk memastikan suplai darah nasional tetap tercukupi selama periode Circuit Breaker (Pembatasan Sosial Berskala Besar) berlangsung di Singapura. Pelaksanaan aksi bertempat di kantor pusat SGI di Singapura pada tanggal 16 Mei 2020 (Singapore Soka Association, 2020d; Soka.Singapore, 2020c; Soka.Singapore, 2020d). Ketika aksi berlangsung, penyelenggara mengecek kesehatan pendonor terlebih dahulu, mengontrol antrian, dan mengatur jarak sebagai upaya pencegahan Covid-19. Aksi donor darah berlangsung lancar dengan berbagai kalangan menjadi pendonor mulai dari anggota SGI, anggota SRC, dan khalayak umum (Singapore Soka Association, 2020e; Soka.Singapore, 2020e).

Untuk praktik anggota SGI di Filipina, mereka diundang menjadi partisipan penggalangan dana secara daring dalam acara “\#KaBayanihan” pada tanggal 7 Juli 2020. Acara ini adalah dialog nasional antara pemerintah pusat, pemerintah daerah, dan generasi muda dari setiap NGO di Filipina yang diadakan oleh United Nations Population Fund (UNFPA). Topik dialog yang diangkat mulai dari kesehatan, pendidikan, kesempatan ekonomi, Hak Asasi Manusia, hingga perdamaian dan keamanan. Selain penggalangan dana, acara ini juga menyelenggarakan kompetisi fotografi, pembacaan puisi, dan pembuatan poster yang bertemakan generasi muda di tengah pandemi. Dana yang terkumpul disalurkan kepada orang-orang yang terdampak Covid-19 serta hibah bagi NGO dengan proposal program inovatif untuk topik-topik di atas (Sgiphilyd, 2020).

\section{Persepsi SGI terhadap Ancaman dan Perlindungan Manusia dari Covid-19}

Sebelum Covid-19 dinyatakan sebagai pandemi oleh WHO, Ikeda sempat terlebih dahulu merilis “proposal perdamaian” untuk tahun 2020. Hal ini adalah pemikiran Ikeda mengenai komitmen yang diperlukan untuk memastikan keamanan dan perdamaian bagi manusia secara global. Komitmen tersebut sebagai berikut: 1) tidak pernah meninggalkan individu atau kelompok yang sedang mengalami keadaan sulit; 2) ikut ambil bagian dalam tindakan nyata untuk mengatasi ancaman bersama; 3) generasi muda menjadi elemen tidak terpisahkan dalam pembangunan berkelanjutan; 4) realisasi masyarakat berkelanjutan yang memiliki rasa aman; 5) tata kelola multilateral untuk menghentikan ancaman; 6) konsisten mengatasi ancaman terkini seperti 
perubahan iklim dan bencana alam; serta 7) melindungi hak asasi manusia dan pembangunan berkelanjutan untuk generasi mendatang. Poin utama dari komitmen tersebut adalah menyadarkan manusia untuk memiliki solidaritas demi menjamin keamanan dan perdamaian bersama (Ikeda, 2020).

Ikeda memberikan arahan bagi anggota SGI terkait penyebaran Covid-19 pada bulan Maret 2020. Setiap anggota diharapkan untuk berkomitmen untuk meringankan penderitaan dan menyebarluaskan kebahagian kepada masyarakat di tengah pandemi (dalam Fisker-Nielsen, 2020: 30-31). Selain itu, Ikeda memberikan arahan lagi bagi anggota SGI mengenai upaya bersama untuk melawan Covid-19 pada bulan April 2020. Ikeda mengingatkan setiap anggota untuk menjalankan ajaran Nichiren "membangun pembelajaran yang benar untuk perdamaian dunia". Setiap anggota SGI di berbagai negara dapat bersatu membentuk ketertiban dan ketentraman ketika pandemi dengan berkontribusi secara tulus untuk masyarakat sekitar. Bagi Ikeda, setiap manusia memiliki sifat alamiah untuk membantu satu sama lain di tengah masa sulit (Fisker-Nielsen, 2020).

Masih di bulan yang sama, Ikeda memublikasikan esai yang mengangkat tema Covid-19. Ikeda memberikan dorongan semangat dan apresiasi bagi tenaga medis dan masyarakat di seluruh dunia dalam upaya penghentian penyebaran Covid-19. Ini menjadi tantangan bersama yang melelahkan bagi setiap individu di berbagai tempat. Covid-19 adalah ancaman yang perlu diakhiri dengan cepat agar kehidupan manusia kembali normal dan aman (SGI-USA, 2020a). Ikeda menyatakan juga bahwa ancaman Covid-19 perlu ditangani dengan partisipasi manusia di seluruh dunia dalam kerja sama yang berdasarkan pada kekuatan, kebijaksanaan, dan keyakinan untuk membuat era lebih baik. Manusia perlu untuk memperluas dan mengembangkan pergerakan untuk mengatasi setiap permasalahan yang mengancam (SGI-USA, 2020a: 3-6).

Pada bulan April 2020, Harada Minoru selaku Presiden SGI saat ini menyatakan organisasi mereka memiliki determinasi untuk terlibat aktif dalam mengatasi ancaman Covid-19 dengan didasarkan pada ajaran Nichiren "mengubah racun menjadi obat". Ajaran ini memiliki arti di tengah periode yang paling meresahkan dan menyulitkan tetap terdapat pembelajaran baru untuk menguatkan jaringan kemanusiaan dalam cakupan global (Soka Gakkai International, 2020: 4). Kemudian, Harada juga meyakini setiap anggota SGI di berbagai negara ikut mengatasi pandemi sesuai dengan kapasitas kelembagaan serta situasi di masing-masing negara. Setiap anggota SGI dapat memiliki kesempatan yang sama untuk membantu penanganan Covid-19 dengan penuh tanggung jawab. Praktik-praktik SGI ketika Covid-19 memiliki orientasi sesuai pembangunan 
berkelanjutan dengan memastikan tidak ada yang tertinggal dalam kondisi menyulitkan (Soka Gakkai International, 2020: 1-3).

Harada menyatakan dalam siaran pers SGI bulan April 2020 bahwa penyebaran Covid-19 menghadirkan kondisi darurat, sehingga memerlukan upaya ganda untuk menyelamatkan nyawa manusia yang berharga. Pandemi Covid-19 adalah periode sulit untuk manusia terutama bagi korban dan tenaga medis di seluruh dunia. Covid-19 memberikan pengaruh dan dampak yang menghancurkan bagi kehidupan manusia secara global. Manusia menjadi sulit untuk beraktivitas guna memenuhi kebutuhan hidup sehari-hari akibat Covid-19 (Soka Gakkai International, 2020). Harada menambahkan pandemi ini menghadirkan kondisi tidak terduga yang dipenuhi oleh kecemasan, ketidakpastian, dan kesepian bagi manusia. Kondisi demikian sebenarnya dapat membantu manusia untuk meningkatkan rasa kebersamaan tetapi juga dapat memperburuk perpecahan antarmanusia (Soka Gakkai International, 2020: 5).

Ikeda kembali memberikan arahan bagi anggota SGI di seluruh dunia terkait Covid-19 pada bulan Mei dan Juni 2020. Ikeda menyampaikan bahwa keberadaan pandemi Covid-19 adalah tantangan berat bagi setiap manusia, sehingga semua orang sedang fokus menjalankan tugas masing-masing di ruang lingkup yang berbeda-beda. Walaupun memiliki tugas berbeda, semua orang berupaya untuk mencapai tujuan yang sama yaitu kesehatan dan keselamatan bagi masyarakat (SGI-USA, 2020b). Ikeda menyampaikan juga bahwa penting untuk tidak pernah menyerah di periode pandemi ini. Semangat untuk berjuang perlu dijaga oleh setiap manusia dalam menghentikan penyebaran Covid-19. Lebih lanjut, Ikeda yakin kemenangan melawan ancaman Covid-19 tentu akan dapat diraih dengan usaha bersama (SGI-USA, 2020c).

Dari pernyataan beberapa tokoh SGI di atas dapat dilihat persepsi ancaman Covid-19 bagi keamanan manusia sejak Maret 2020. Covid-19 dipandang oleh SGI sebagai tantangan yang menghadirkan kondisi darurat bagi manusia. Covid-19 hadir secara tidak terduga dan dengan begitu saja menghancurkan banyak aspek kehidupan manusia. Hal seperti ini membuat langkah bersama antarmanusia penting untuk menghentikan penyebaran Covid-19 di dunia menurut SGI. Setiap manusia memiliki tanggung jawab untuk berpartisipasi dalam mengatasi ancaman Covid19 sesuai dengan kapasitas yang dimilikinya. SGI memiliki keyakinan bahwa ancaman Covid-19 tetap bisa teratasi secara tuntas dan cepat dengan upaya bersama secara global, sehingga kehidupan manusia kembali aman lagi. Dengan temuan tersebut, SGI dapat dikatakan hirau terhadap keamanan manusia karena Covid-19 dipandang sebagai ancaman yang dapat merusak 
penghidupan dan kesejahteraan setiap manusia. SGI juga menyadari ancaman yang seperti ini memerlukan tanggung jawab kolektif dari banyak aktor agar dapat diatas. Lebih lanjut, beberapa pakar memiliki penjelasan tersendiri mengenai persepsi SGI terhadap ancaman Covid-19 bagi manusia.

Berbagai pandangan dari tokoh SGI terhadap ancaman Covid-19 menurut pendapat FiskerNielsen (2020: 25) tidak terlepas dari kesadaran akan kebutuhan untuk merespons pandemi dengan segera. Persepsi ancaman yang dihadirkan oleh SGI menegaskan Covid-19 adalah kondisi darurat bagi jaringan masyarakat secara global. Covid-19 sudah menjadi permasalahan yang secara signifikan memberikan rasa takut bagi manusia di seluruh dunia. Selain itu, persepsi SGI terhadap Covid-19 menurut Fisker-Nielsen (2020: 43) memberikan perhatian juga pada kondisi manusia yang saling terkait ketika ada permasalahan global. Manusia baik sebagai individu maupun bagian dari masyarakat dapat dengan begitu saja terjebak dalam kondisi yang sama akibat ancaman global. Situasi seperti ini bagi SGI tidak dapat dihindari dan perlu ada perhatian bersama dalam mengatasinya.

Sementara itu, McLaughlin (2020: 3-5) mempunyai argumen berupa persepsi SGI terhadap ancaman Covid-19 dibentuk oleh kejadian masa lalu yang kurang lebih serupa serta SGI mengalami permasalahan yang sama dengan khalayak umum. SGI adalah NGO yang sudah berdiri cukup lama, sehingga mengalami berbagai permasalahan yang diakibatkan oleh wabah dan bencana alam. SGI memiliki kesadaran akan dampak buruk pandemi di berbagai bidang yang sudah menimpa manusia periode lampau. Kemudian, ketika Covid-19 terjadi, SGI juga mengalami kendala dalam melakukan praktiknya. Kantor SGI di setiap negara ditutup dan anggota dikarantina di rumah masing-masing untuk mencegah penyebaran Covid-19. Hal seperti ini dialami oleh masyarakat pada umumnya, tidak khusus bagi anggota SGI saja.

Daoudi (2020: 4-5) menunjukkan bahwa Covid-19 memiliki karakteristik alamiah yang merusak berbagai aspek kehidupan. Dengan karakteristik ini, ancaman Covid-19 berdampak meluap yang tidak hanya ke berbagai bidang tetapi juga ke berbagai aktor. Pandemi Covid-19 memberikan ketidakpastian bagi manusia karena sulit untuk diatasi tetapi memiliki efek membahayakan. Lebih lanjut, Daoudi (2020: 5-11) menyatakan bahwa Covid-19 mendorong munculnya berbagai agenda keamanan manusia dari setiap aktor hubungan internasional yang didasarkan pada berbagai pandangan atau persepsi terhadap ancaman. Fakta terkait pandemi seperti pertumbuhan jumlah kasus terkonfirmasi membuat setiap aktor memiliki pemahaman 
lengkap akan kondisi genting yang sedang terjadi. Dengan kata lain, timbul urgensi atas keamanan manusia dengan wabah Covid-19.

Berdasarkan pandangan tokoh SGI di atas juga, dapat dikatakan mereka mendorong anggota SGI agar berkontribusi ke masyarakat melalui praktik kelembagaan. Kontribusi aktif yang sejalan dengan visi global seperti pembangunan berkelanjutan menjadi penting untuk direalisasikan di tengah penyebaran Covid-19. Hal tersebut diperlihatkan dari praktik SGI dengan melakukan sosialisasi informasi dan peringatan terkait ancaman Covid-19 ke masyarakat, menyalurkan bantuan berupa alat kesehatan dan bahan pokok bagi orang yang rentan atau terdampak langsung oleh Covid-19 seperti tenaga medis dan penduduk lansia, mematuhi berbagai panduan pencegahan Covid-19 yang dirilis oleh pemerintah dan IGO, serta berkolaborasi dengan aktor lain seperti palang merah dan IGO untuk mendukung penanganan Covid-19. Praktik SGI yang seperti ini tentu berarti untuk mendukung perlindungan manusia dari dampak buruk yang diakibatkan Covid-19. Berkenaan dengan diskusi bagian ini, beberapa pakar memiliki argumen tambahan untuk menjelaskan praktik-praktik yang dilakukan oleh SGI untuk mendukung perlindungan manusia ketika Covid-19.

Viera dkk (2020: 40) berpendapat pandemi Covid-19 membuat banyak pihak sulit untuk menentukan prioritas kalangan yang perlu diberikan perhatian dalam upaya penghentian wabah. Populasi manusia banyak yang rentan terhadap Covid-19, sehingga di satu sisi tidak dapat dengan mudah untuk menentukan yang lebih dahulu perlu diberikan pertolongan. Mulai dari masyarakat terpencil, tunawisma, pekerja migran, pengungsi, hingga tenaga medis yang menangani pandemi. Berbagai kalangan tersebut memiliki latar belakang yang beragam dan memiliki alasan yang samasama relevan untuk dijadikan fokus utama selama pandemi berlangsung. Kompleksitas ini membuat berbagai langkah perlindungan dari ancaman Covid-19 tidak cukup mengandalkan satu pihak saja. Viera dkk (2020) menambahkan juga bahwa Pemerintah yang biasanya dijadikan andalan untuk penyelesaian masalah tidak cukup mampu. Penanganan Covid-19 memerlukan aksi kolektif dalam skala global dari banyak pihak.

Argumen selanjutnya dari Fisker-Nielsen (2020: 34) menyatakan praktik-praktik SGI untuk mendukung perlindungan dari ancaman Covid-19 dilandasi oleh pembelajaran dari ajaran Nichiren serta arahan Ikeda. Berdasarkan korespondensi dengan anggota SGI, Fisker-Nielsen (2020: 44) menemukan pembelajaran tersebut mendorong mereka untuk melihat kesulitan sebagai kesempatan untuk bertindak secara aktual. Berlangsungya pandemi Covid-19 memberikan 
pembaharuan bagi tujuan atau misi dari praktik kegiatan organisasi SGI agar lebih tanggap untuk mempraktikan rasa kemanusiaan di tengah masyarakat. Anggota SGI menyatakan pandemi ini adalah waktu yang penting untuk memperkuat tanggung jawab sosial kepada masyarakat (FiskerNielsen, 2020). Dengan hal ini, Covid-19 dapat dikatakan menjadi momentum bagi SGI untuk meningkatkan praktik yang mendukung implementasi pembangunan berkelanjutan di tengah masyarakat dalam keadaan darurat.

Berkaitan dengan persepsi SGI terhadap ancaman dan upaya perlindungan manusia di bagian awal, ada kritisisme dari beberapa pakar yang meragukan tujuan mulia organisasi tersebut untuk membantu masyarakat. Secara umum, pakar-pakar ini berpandangan momen darurat seperti wabah penyakit, bencana alam, maupun krisis kemanusiaan memberikan kesempatan bagi aktor untuk mengeksploitasinya guna mendapatkan perolehan menguntungkan baik secara materi, dominasi, dan sebagainya. Aktor yang menjalankan skema ini tidak terbatas aktor negara dan perusahaan multinasional saja tetapi juga NGO. Fenomena tersebut menurut Klein (2007) sudah lazim dan menjadi lebih intens dalam tiga puluh tahun terakhir. Berikut pendapat beberapa pakar mengenai hal ini pada kasus Covid-19 dan SGI.

Filho dkk (2020) berpendapat bahwa pandemi Covid-19 dapat menjadi ancaman bagi solidaritas kemanusiaan global. Covid-19 menghadirkan kondisi yang menyulitkan bagi banyak orang seperti krisis ekonomi, peningkatan kemiskinan, hingga gagalnya sistem kesejahteraan sosial. Dengan hal tersebut, pandemi ini justru mendorong banyak orang untuk memperoleh keuntungan semaksimal mungkin. Filho dkk (2020) menyebut hal ini sebagai kapitalisme baru yaitu memperoleh keuntungan jangka pendek maupun panjang di tengah bencana. Berbagai aktor boleh jadi menggunakan momen darurat ini untuk menjustifikasi berbagai tindakan yang berorientasi tidak semata memberikan pertolongan tetapi juga memperoleh keuntungan. Filho dkk (2020) memberikan contoh NGO selaku aktor yang aktif dalam kondisi pandemi boleh jadi mengejar timbal balik berupa donasi. Tentu ini dapat dianggap mengganggu proses implementasi pembangunan berkelanjutan global karena tidak mendahulukan kepentingan orang banyak secara sukarela.

Khusus untuk SGI, Brok dan Williams-Oerberg (2017) memiliki argumen berupa mereka juga termasuk sebagai organisasi yang berorientasi memperoleh donasi sebanyak-banyak dalam momen tertentu. Praktik SGI sebenarnya berkaitan erat dengan pemenuhan kebutuhan untuk keberlangsungan hidup organisasi. Sebagai NGO, sumber pendanaan utama SGI adalah iuran serta 
donasi dari anggota. Oleh karena itu, SGI secara aktif menjalankan berbagai praktik yang mampu menarik simpati masyarakat dengan harapan ada yang tertarik untuk bergabung dalam organisasi. Lebih lanjut, timbal balik seperti ini juga mendukung peroleh secara material. Dengan keanggotaan yang semakin banyak, sumber pendanaan untuk operasional kelembagaan dapat terjamin. Brok dan Williams-Oerberg (2017) sendiri menyebut skema ini sebagai titik temu antara komodifikasi dan penjenamaan (branding) dari praktik NGO. Praktik NGO dirancang sebagai komoditas yang laku di masyarakat.

Permasalahan SGI ini sempat dibahas juga oleh Hefner (2010) dengan mengangkat kasus di Asia Tenggara. Kawasan tersebut menjadi wilayah operasi yang paling diminati oleh SGI karena memiliki keragaman kultural maupun tingkat kesejahteraan. Banyaknya etnis dan kepercayaan yang berkembang di Asia Tenggara membuat SGI dapat mudah hadir. Kemudian, kondisi ekonomi masyarakat di Asia Tenggara yang timpang membuat praktik penyaluran bantuan oleh SGI menjadi relevan. Dua karakteristik ini menurut Hefner (2010) memberikan kesempatan bagi SGI dalam mengembangkan perekrutan dan kegiatan organisasi karena masyarakatnya cenderung patuh, religius, dan populis. Masyarakat dapat dengan mudah terpikat dengan kegiatan kelembagaan, memberikan donasi sebagai bentuk apresiasi, dan ikut terlibat dalam struktur organisasi. Dengan kata lain, Asia Tenggara adalah kawasan yang menjanjikan untuk pengembangan jaringan keanggotaan SGI sebagai NGO yang berbasis keagamaan.

Soka News (2018), Hammouda (2019), dan Introvigne (2019) menunjukkan bahwa kontroversi SGI di atas menghadirkan penolakan atau pembatasan terhadap praktik mereka di beberapa negara seperti Jepang, Italia, dan Perancis. Praktik-praktik SGI di bidang kemanusiaan, pendidikan, dan budaya dipermasalahkan karena pemerintah dan masyarakat tiga negara tersebut memiliki anggapan tujuan SGI sebenarnya hanya memperbanyak anggota di suatu negara serta mengembangkan jaringan keanggotaan di berbagai negara. Pemerintah Italia dan Perancis melakukan pembatasan jumlah anggota dan memusatkan kegiatan organisasi SGI di satu kota saja. Sementara itu, masyarakat Italia dan Perancis sendiri dapat dikatakan memiliki sentimen negatif yang tidak begitu menerima kehadiran SGI karena dianggap sebagai sesuatu yang asing (Hammouda, 2019; Introvigne, 2019). Untuk di Jepang, terdapat juga kelompok yang membuat situs daring untuk mengkritisi praktik SGI (Soka News, 2018). 


\section{Simpulan}

Artikel ini berupaya untuk mendeskripsikan praktik SGI di dalam mendukung keamanan manusia di Indonesia, Filipina, dan Singapura ketika pandemi Covid-19. Berdasarkan temuan dan pembahasan di atas, artikel ini menyimpulkan bahwa SGI di tiga negara tersebut sudah menjalankan beberapa praktik dalam rangka mendukung upaya perlindungan manusia dari ancaman Covid-19 tetapi intensi sebenarnya dari praktik keamanan manusia mereka masih diperdebatkan oleh beberapa pakar. Walaupun SGI mengklaim berbagai praktik mereka selama pandemi didasarkan pada kesadaran akan bahaya Covid-19, jika meninjau praktik-praktik SGI sebelumnya di situasi yang serupa maka beberapa kajian menyatakan momen darurat seperti ini dapat digunakan untuk memperoleh timbal balik berupa keanggotaan dan donasi. Hal tersebut juga secara konseptual tidak terlepas dari keamanan manusia yang cenderung mementingkan banyak aktor saja, sehingga memungkinkan maksud sebenarnya dari suatu aktor dapat tertutupi oleh upaya perlindungan.

Artikel ini masih memiliki keterbatasan dalam mendeskripsikan berbagai praktik SGI di Indonesia, Filipina, dan Singapura sebagai praktik keamanan manusia ketika Covid-19. Artikel ini tidak mendalami efektivitas praktik SGI di tiga negara tersebut selama pandemi. Tanggapan masyarakat perlu menjadi perhatian untuk menggambarkan kebermanfaatan dari praktik SGI. Apresiasi maupun penolakan dari masyarakat terhadap praktik-praktik SGI adalah pengayaan yang dapat memperluas diskusi topik ini. Kemudian, rentang waktu yang diambil dalam artikel ini dapat dikatakan pendek, yaitu Maret hingga Juli 2020. Terlebih, pandemi Covid-19 hingga penulisan artikel ini masing berlangsung secara global. Oleh karena itu, temuan dan simpulan yang ada dalam artikel dapat dikatakan masih awal atau sementara. Sangat mungkin sekali terdapat perkembangan aktivitas maupun kajian mengenai SGI di Indonesia, Filipina, dan Singapura dalam waktu dekat. Selain itu, pengayaan dalam artikel ini masih memiliki topik yang perlu diinvestigasi lebih lanjut yaitu pemanfaatan pandemi sebagai momen krusial bagi SGI untuk memperoleh keuntungan optimal.

Dengan keterbatasan di atas juga, hal selanjutnya yang perlu penelusuran mendalam adalah praktik keamanan manusia oleh aktor lain ketika pandemi Covid-19. Inti dari praktik keamanan manusia adalah setiap aktor dapat terlibat aktif dalam langkah perlindungan dari ancaman yang membahayakan manusia. Kompleksitas ancaman dan kerentanan manusia yang menjadi perhatian utama dalam keamanan manusia memerlukan praktik dengan tanggung jawab kolektif agar 
"freedom from want" tercapai di berbagai keadaan. Dengan kata lain, rangkaian praktik yang mendukung keamanan manusia di tengah pandemi dari waktu ke waktu dapat ditemukan juga di aktor lain. Praktik serupa maupun praktik yang lebih berkembang dibandingkan SGI boleh jadi sudah dilakukan tetapi belum terbahas. Pembahasan seperti ini tentu diperlukan agar pembelajaran mengenai praktik keamanan manusia oleh berbagai macam aktor ketika pandemi Covid-19 menjadi lebih lengkap.

\section{Referensi}

Acharya, A. (2001). Human Security: East versus West. International Journal, 56(3), 442-460. Acharya, A. (2014). Human Security. In S. S. J. Baylis, The Globalization of World Politics: An Introduction to International Relations (pp. 448-462). New York: Oxford University Press.

Brox, T., \& Williams-Oerberg, E. (2017). Buddhism, Business, and Economics. In M. Jerryson, The Oxford Handbook of Contemporary Buddhism (pp. 504-517). New York: Oxford University Press.

Carr, A., \& Wallis, J. (2016). An Introduction to Asia-Pacific Security. In J. Wallis, \& A. Carr, Asia-Pacific Security: An Introduction (pp. 1-20). Washington, D. C.: Georgetown University Press.

Cherry, S. M., \& Ebaugh, H. R. (2016). Global Religious Movements Across Borders: Sacred Service. New York: Routledge.

Commision on Human Security. (2003). Human Security Now: Protecting and Empowering People. New York: United Nations.

Daoudi, S. (2020). The War on COVID-19: The 9/11 of Health Security? Rabat: Policy Center for The New South.

Davies, T. (2019). Routledge Handbook of NGOs and International Relations. New York: Routledge.

Duffield, M. (2007). Development Security and Unending War: Governing the World of Peoples. Cambridge: Polity Press.

Dunne, T. M., Kurki, M., \& Smith, S. (2013). nternational Relations: Discipline and Diversity. New York: Oxford University Press.

Filho, L. W., Brandli, L. L., Salvia, A. L., Rayman-Bacchus, L., \& Platje., J. (2020). COVID-19 and the UN Sustainable Development Goals: Threat to Solidarity or an Opportunity? Sustainbility, 12(13), 1-14.

Fisker-Nielsen, A. M. (2012). Religion and Politics in Contemporary Japan: Soka Gakkai Youth and Komeito. New York: Routledge.

Fisker-Nielsen, A. M. (2020). Response of Soka Gakkai to the COVID-19 Pandemic: Personhood, Interiority, and a Civil Society in Crisis Mode. The Journal of CESNUR, 4(3), 25-48.

Gagné, I. (2017). Religious Globalization and Reflexive Secularization in a Japanese New Religion. Japan Review(75), 153-177.

Goulah, J. (2020). Daisaku Ikeda and the Soka movement for global citizenship. Asia Pacific Journal of Education, 40(1), 35-48. 
Griffiths, M., O'Callaghan, T., \& Roach, S. C. (2008). International Relations: The Key Concepts. New York: Routledge.

Hammouda, Y. B. (2019). The Limits of Religious Tolerance in France: The Case of Soka Gakkai. The Journal of CESNUR, 3(6), 32-47.

Hampson, F. O. (2013). Human Security. In P. D. Williams, Security Studies: An Introduction (pp. 279-294). New York: Routledge.

Haq, M. (1995). Reflection on Human Development. Oxford: Oxford Univeristy Press.

Hefner, R. W. (2010). Religious Resurgence in Contemporary Asia: Southeast Asian Perspectives on Capitalism, the State, and the New Piety. The Journal of Asian Studies, 69(4), 1031-1047.

Heins, V. (2008). Nongovernmental Organizations in International Society: Struggles Over Recongnition. New York: Palgrave.

Heywood, A. (2011). Global Politics. New York: Routledge.

Holliday, I., \& Howe, B. M. (2011). Human Security: A Global Responsibility to Protect and Provide. Korean Journal of Defense Analysis, 23(1), 73-91.

Hough, P. (2013). Understanding Global Security. New York: Routledge.

Ikeda, D. (2020). Peace Proposal, Towards Our Shared Future: Constructing an Era of Human Solidarity. Retrieved from Daisaku Ikeda: https://www.daisakuikeda.org/assets/files/peaceproposal2020.pdf

Introvigne, M. (2019). Soka Gakkai in Italy: Success and Controversies. The Journal of CESNUR, 3(6), 3-17.

Klein, N. (2007). The Shock Doctrine: The Rise of Disaster Capitalism. New York: Metropolitan Books.

Lamont, C. (2015). Research Methods in International Relations. London: SAGE.

Machachek, D., \& Wilson., B. R. (2000). Global Citizens: The Soka Gakkai Buddhist Movement in the World. New York: Oxford University Press.

Malik, S. (2015). Human Security. In P. Hough, A. M. S. Malik, \& B. Pilbeam, International Security Studies: Theory and Practice (pp. 57-71). New York: Routledge.

Martin, L. L., \& Simmons, B. A. (2012). International Organizations and Institutions. In W. Carlsnaes, T. Risse, \& B. A. Simmons, Handbook of International Relations (pp. 326351). London: SAGE.

McGlinchey, S., Walters, R., \& Scheinpflug, C. (2017). International Relations Theory. Bristol: E-International Relations.

McGrew, A. (2014). Globalization and Global Politics. In J. Baylis, S. Smith, \& P. Owens, The Globalization of World Politics: An Introduction to International Relations (pp. 15-31). New York: Oxford University Press.

McLaughlin, L. (2016). Hard Lessons Learned: Tracking Changes in Media Presentations of Religion and Religious Aid Mobilization after the 1995 and 2011 Disasters in Japan. Asian Ethnology, 75(1), 105-137.

McLaughlin, L. (2020). Japanese Religious Responses to COVID-19: A Preliminary Report. Japan Focus: The Asia-Pacific Journal, 18(9), 1-23.

Panno, A., Giacomantonio, M., Carrus, G., Maricchiolo, F., Pirchio, S., \& Mannetti, L. (2018). Mindfulness, Pro-environmental Behavior, and Belief in Climate Change: The Mediating Role of Social Dominance. Environment and Behavior, 50(8), 864-888.

Seager, R. H. (2006). Encountering the Dharma: Daisaku Ikeda, Soka Gakkai, and the Globalization of Buddhist Humanism. Berkeley: University of California Press. 
SGI Indonesia. (2020). Berbagi Harapan dan Keberanian - 1: Upaya Kemanusiaan Anggota SGI Merespons Covid-19. Retrieved from SGI Indonesia: https://www.sgiindonesia.or.id/komunitas/berita/berita-detail/berbagi-harapan-dan-keberanian-1-upayakemanusiaan-anggota-sgi-merespons-covid-19

Sgiphilyd. (2020). Kiriman Halaman Facebook SGI-Philippines Youth Division tanggal 30 Mei 2020. Retrieved from Facebook: https://www.facebook.com/463319617513221/posts/882860948892417

SGI-USA. (2020a). "Become Pioneers of a Better Age”: SGI President Ikeda's encouragement on facing the coronavirus(COVID-19) pandemic. Retrieved from World Tribune: https://www.worldtribune.org/2020/03/become-pioneers-of-a-better-age/

SGI-USA. (2020b). Upholding an Invincible Spirit: Ikeda Sensei's Guidance. Retrieved from World Tribune: https://www.worldtribune.org/article/upholding-an-invincible-spirit/

SGI-USA. (2020c). Upholding an Invincible Spirit Part 2 of 2: Ikeda Sensei's Guidance. Retrieved from World Tribune: https://www.worldtribune.org/article/upholding-aninvincible-spirit-part-2-of-2/

Singapore Soka Association. (2020a). Reaching Out to Seniors with No Caregivers. Retrieved from SSA Buddhist: https://ssabuddhist.org/reaching-out-to-seniors-with-nocaregivers/\#.XwzoV1MxXqu

Singapore Soka Association. (2020b). Youth Step Forward for BYOB-Free Sanitizer Collection Exercise. Retrieved from SSA Buddhist: https://ssabuddhist.org/youth-step-forward-forbyob-free-sanitizer-collection-exercise/\#.Xw1NTygza01

Singapore Soka Association. (2020c). Inspiring Hope and Joy in Others Amid Covid-19 daily! Retrieved from SSA Buddhist: https://ssabuddhist.org/inspiring-hope-and-joy-in-otheramid-covid-19-daily/\#.Xw1zRCgza00

Singapore Soka Association. (2020d). Blood Donation Drive in Partnership with Singapore Red Cross. Retrieved from SSA Buddhist: https://ssabuddhist.org/blood-donation-drive2020/\#.Xw1W4Cgza01

Singapore Soka Association. (2020e). SSA supports Blood Donation Drive by Singapore Red Cross. Retrieved from SSA Buddhist: https://ssabuddhist.org/ssa-supports-blooddonation-drive-by-singapore-red-cross/\#.Xw1W3Cgza02

Snyder, J. (2009). One World, Rival Theories. Foreign Policy, 145, 52-62.

Soka Gakkai International. (2015a). SGI: A Snapshot. Retrieved from Soka Gakkai International: https://www.sgi.org/snapshot/

Soka Gakkai International. (2015b). Budhist Lineage. Retrieved from Soka Gakkai International: https://www.sgi.org/about-us/buddhist-lineage/

Soka Gakkai International. (2020). A Message from Soka Gakkai President Minoru Harada. Retrieved from Soka Gakkai International: https://www.sgi.org/in-focus/pressreleases/response-to-covid-19-pandemic.html

Soka News. (2018). Site for Understanding SGI. Retrieved from Soka News: https://www.sokanews.jp/dakkai.html

Soka.Singapore. (2020a). Kiriman Akun Instagram Singapore Soka Association tanggal 27 Maret 2020. Retrieved from Instagram: https://www.instagram.com/p/B-QmZTtDsc1/

Soka.Singapore. (2020b). Kiriman Akun Instagram Singapore Soka Association tanggal 30 Maret 2020. Retrieved from Instagram: https:/www.instagram.com/p/B-YVoaLjstM/

Soka.Singapore. (2020c). Kiriman Akun Instagram Singapore Soka Association tanggal 9 Mei 2020. Retrieved from Instagram: https://www.instagram.com/p/B_8mO1PD83Z/ 
Soka.Singapore. (2020d). Kiriman Akun Instagram Singapore Soka Association tanggal 15 Mei 2020. Retrieved from Instagram: https://www.instagram.com/p/CAMFqoLjUdF/

Soka.Singapore. (2020e). Kiriman Akun Instagram Singapore Soka Association tanggal 19 Mei 2020. Retrieved from Instagram: https://www.instagram.com/p/CAWXXrnDhhP/

SokaGakkaiIndonesiainfo. (2020a). Kiriman Halaman Facebook Soka Gakka Indonesia tanggal 13 Maret 2020. Retrieved from Facebook: https://www.facebook.com/905481186293082/posts/1504149289759599/

SokaGakkaiIndonesiainfo. (2020b). Kiriman Halaman Facebook Soka Gakka Indonesia tanggal 19 Maret 2020. Retrieved from Facebook:

https://www.facebook.com/905481186293082/posts/1509583412549520/

SokaGakkaiIndonesiainfo. (2020c). Kiriman Halaman Facebook Soka Gakka Indonesia tanggal 30 Maret 2020. Retrieved from Facebook: https://www.facebook.com/905481186293082/posts/1518826408291887/

SokaGakkaiIndonesiainfo. (2020d). Kiriman Halaman Facebook Soka Gakka Indonesia tanggal 15 April 2020. Retrieved from Facebook:

https://www.facebook.com/SokaGakkaiIndonesiainfo/photos/a.1171834579657740/1532 $977630210098 /$ type $=3$

SokaGakkaiIndonesiainfo. (2020e). Kiriman Halaman Facebook Soka Gakka Indonesia tanggal 28 April 2020. Retrieved from Facebook:

https://www.facebook.com/SokaGakkaiIndonesiainfo/photos/a.1171834579657740/1532 977630210098/?type $=3$

Šoryte, R. (2019). Soka Gakkai’s Campaigns for Nuclear Disarmament. The Journal of CESNUR, 3(6), 18-31.

Steans, J., Pettiford, L., \& Diez, T. (2013). An Introduction to International Theory: Perspectives and Themes. New York: Routledge.

Tajbakhsh, S., \& Chenoy, A. M. (2006). Human Security: Concepts and Implications. London: Routledge.

Teitt, S. (2016). Is Human Security a Solution? In J. Wallis, \& A. Carr, Asia-Pacific Security: An Introduction (pp. 241-258). Washington, D. C.: Georgetown University Press.

United Nations Development Programme. (1995). Human Development Report 1994. Oxford: Oxford Univeristy Press.

Vieira, C. M., Franco, O. H., Restrepo, C. G., \& Abel, T. (2020). COVID-19: The forgotten priorities of the pandemic. Maturitas, 136, 38-41.

Walt, S. M. (1998). International Relations: One World, Many Theories. Foreign Policy, 110, 29-46.

Weiss, T. G., \& Gordenker, L. (1996). NGOs, the UN and Global Governance. Boulder: Lynne Reinner.

Willetts, P. (1996). The Conscience of the World: The Influence of Non-Governmental Organization in the UN System. London: Hurst and Co.

Willetts, P. (2010). Non-Governmental Organization in World Politics: The Construction of Global Governance. London: Routledge.

Willetts, P. (2014). Transnational Actors and International Organizations in Global Politics. In J. Baylis, S. Smith, \& P. Owen, The Globalization of World Politics: An Introduction to International Relations (pp. 320-336). New York: Oxford University Press.

Williams, P. D. (2013). Security Studies: An Introduction. In P. D. Williams, Security Studies: An Introduction (pp. 1-12). New York: Routledge. 
World Health Organization. (2020a). WHO Director-General's opening remarks at the media briefing on COVID-19 - 11 March 2020. Retrieved from World Health Organization: https://www.who.int/dg/speeches/detail/who-director-general-s-opening-remarks-at-themedia-briefing-on-covid-19---11-march-2020

World Health Organization. (2020b). Q\&A on coronaviruses (COVID-19). Retrieved from World Health Organization: https://www.who.int/emergencies/diseases/novelcoronavirus-2019/question-and-answers-hub/q-a-detail/q-a-coronaviruses

World Health Organization. (2020c). WHO Coronavirus Disease (COVID-19) Dashboard. Retrieved from World Health Organization: https://covid19.who.int/

Yin, R. K. (2018). Case Study Research and Application: Designs and Methods. London: SAGE. Yuri, I. (2017). Gender and New Religions in Modern Japan. Japanese Journal of Religious Studies, 44(1), 15-35. 